\title{
Novel Carbon Materials in the Cathode Formulation for High Rate Rechargeable Hybrid Aqueous Batteries
}

\author{
Xiao Zhu, Tuan K. A. Hoang and Pu Chen * \\ Department of Chemical Engineering and Waterloo Institute for Nanotechnology, University of Waterloo, \\ 200 University Avenue West, Waterloo, ON N2L 3G1, Canada; x58zhu@uwaterloo.ca (X.Z.); \\ tuanchemistry@gmail.com (T.K.A.H.) \\ * Correspondence: p4chen@uwaterloo.ca; Tel.: +1-519-888-4567 (ext. 35586)
}

Received: 27 September 2017; Accepted: 8 November 2017; Published: 11 November 2017

\begin{abstract}
Novel carbon materials, carbon nanotubes (CNTs) and porous graphene (PG), were exploited and used as conductive additives to improve the rate performance of $\mathrm{LiMn}_{2} \mathrm{O}_{4}$ cathode for the rechargeable aqueous $\mathrm{Zn} / \mathrm{LiMn}_{2} \mathrm{O}_{4}$ battery, namely the rechargeable hybrid aqueous battery (ReHAB). Thanks to the long-range conductivity and stable conductive network provided by CNTs, the rate and cycling performances of $\mathrm{LiMn}_{2} \mathrm{O}_{4}$ cathode in ReHAB are highly improved-up to about $100 \mathrm{mAh} \cdot \mathrm{g}^{-1}$ capacity is observed at $10 \mathrm{C}\left(1 \mathrm{C}=120 \mathrm{mAh} \cdot \mathrm{g}^{-1}\right)$. Except for CNTs, porous graphene (PG) with a high surface area, an abundant porous structure, and an excellent electrical conductivity facilitates the transportation of Li ions and electrons, which can also obviously enhance the rate capability of the ReHAB. This is important because the ReHAB could be charged/discharged in a few minutes, and this leads to potential application of the ReHAB in automobile industry.
\end{abstract}

Keywords: carbon nanotube; graphene; $\mathrm{LiMn}_{2} \mathrm{O}_{4}$; rechargeable hybrid aqueous battery; high rate capability

\section{General Introduction of Aqueous Rechargeable Battery}

Batteries are widely used as energy storage systems. Lithium ion batteries can operate at high voltages due to the wide electrochemical stability range of the organic electrolytes $\left(3-5 \mathrm{~V} \mathrm{vs} . \mathrm{Li}^{+} / \mathrm{Li}\right.$ electrode), resulting in high energy densities. Therefore, lithium ion batteries have been widely used in electronic devices and they have been chosen as one of the most promising power sources for electric vehicles (EVs). Unfortunately, these organic electrolytes show high flammability and low ionic conductivity (about two orders of magnitude lower than those of aqueous electrolytes); besides, the fabrication cost of lithium ion batteries is generally high. Aqueous electrolytes are electrochemically stable just in a narrower voltage ( $1.23 \mathrm{~V}$ vs. SHE) than organic electrolytes; however, they are much safer (inherently non-flammable and low toxic) and the fabrication cost of aqueous batteries is much lower than lithium ion batteries, so aqueous batteries are more suitable for low cost and large-scale energy storage [1-3]. Thus far, a variety of aqueous batteries, including alkaline $\mathrm{Zn}-\mathrm{MnO}_{2}$, lead-acid, Ni-Metal (e.g., zinc, cobalt, and iron), and Ni-metal hydride (Ni-MH) are used extensively or studied widely $[1,4-8]$. However, these systems also have their own problems. Specifically, the alkaline $\mathrm{Zn} / \mathrm{MnO}_{2}$ is a primary battery, and its disposal causes plenty of pollution to the environment; the poisoning metals of lead and cadmium utilized in lead-acid and $\mathrm{Ni}-\mathrm{Cd}$ batteries, respectively, may cause damage to the environment; $\mathrm{Ni}-\mathrm{MH}(\mathrm{M}=\mathrm{La}, \mathrm{Ce}, \mathrm{Nd}, \mathrm{Gd}$, etc.) batteries utilize rare earth elements, which makes them expensive; and $\mathrm{Ni}-\mathrm{Co}(\mathrm{Fe}, \mathrm{Zn})$ batteries have narrow voltage range.

Recently, a series of aqueous "rocking-chair" batteries based on the ion (e.g., $\mathrm{Li}^{+}, \mathrm{Na}^{+}, \mathrm{K}^{+}$, and $\mathrm{Zn}^{2+}$ ) intercalation/de-intercalation processes have been developed [9-20]. In 1994, Dahn et al. first 
developed the aqueous $\mathrm{LiMn}_{2} \mathrm{O}_{4} / \mathrm{VO}_{2}$ battery [9], with $\mathrm{LiNO}_{3}$ solution $\left(5 \mathrm{~mol} \cdot \mathrm{L}^{-1}\right)$ as the electrolyte. Then, various kinds of aqueous "rocking-chair" lithium ion batteries (e.g., $\mathrm{LiFePO}_{4} / \mathrm{LiTi}_{2}\left(\mathrm{PO}_{4}\right)_{3}$, $\mathrm{LiMn}_{2} \mathrm{O}_{4} / \mathrm{LiTi}_{2}\left(\mathrm{PO}_{4}\right)_{3}$, and $\left.\mathrm{LiMn}_{2} \mathrm{O}_{4} / \mathrm{LiV}_{3} \mathrm{O}_{8}\right)$ have been reported; [9-12]. Besides, Cui et al. reported a potassium ion battery, using carbon/polypyrrole hybrid and copper hexacyanoferrate as the anode and the cathode. This battery exhibited an excellent rate capability [14]. Different from aqueous lithium or potassium ion batteries, aqueous sodium ion batteries may be more promising to be used as large-scale energy storage systems due to the rich sodium resources in nature. Whitacre's and Chiang's groups both reported aqueous $\mathrm{Na}_{0.44} \mathrm{MnO}_{2} / \mathrm{NaTi}_{2}\left(\mathrm{PO}_{4}\right)_{3}$ batteries $[18,19]$. However, sodium-intercalated compounds for aqueous systems are limited. Unique $\mathrm{Li} / \mathrm{Na}$ mixed ion batteries, $\mathrm{Na}_{0.44} \mathrm{MnO}_{2} / \mathrm{TiP}_{2} \mathrm{O}_{7}$ and $\mathrm{LiMn}_{2} \mathrm{O}_{4} / \mathrm{Na}_{0.22} \mathrm{MnO}_{2}$, were developed by Xia's group, which mainly depend on the intercalation/de-intercalation of $\mathrm{Na}$ ions and $\mathrm{Li}$ ions, respectively. The specific energy of these two batteries was 25 and $17 \mathrm{Wh} \cdot \mathrm{kg}^{-1}$, respectively. It is worth mentioning that $\mathrm{Li}$ ions and $\mathrm{Na}$ ions are separated in aqueous $\mathrm{LiMn}_{2} \mathrm{O}_{4} / \mathrm{Na}_{0.22} \mathrm{MnO}_{2}$ battery due to the special operating mechanism of this system [21]. In addition, Cui et al. found that materials with the Prussian Blue crystal structure (nickel hexacyanoferrate and copper) possess large interstitial sites, which allows for the intercalation/de-intercalation of sodium (potassium) ions $[20,22]$. Their capacities are between 50 and $60 \mathrm{mAh} \cdot \mathrm{g}^{-1}$.

\section{Introduction of Rechargeable Hybrid Aqueous Battery}

New types of aqueous rechargeable batteries, including new electrode materials and chemistry, are required to achieve high power as well as high safety and eco-friendliness. Herein, rechargeable $\mathrm{Zn} / \mathrm{MnO}_{2}$ batteries have been widely studied; however, the redox reactions on the cathode show poor reversibility, which hinders its commercial applications. When electrolytes with $\mathrm{pH} \geq 7, \mathrm{Zn}(\mathrm{OH})_{2}$, $\mathrm{ZnO}_{2}{ }^{2-}$, and $\left[\mathrm{Zn}(\mathrm{OH})_{4}\right]^{2-}$ are formed depending on potential and $\mathrm{pH}$ value, while with $\mathrm{pH}<7$, $\mathrm{Zn}-2 e^{-} \rightarrow \mathrm{Zn}^{2+}$ [23]. Minakshi et al. found that replacing $\mathrm{MnO}_{2}$ by $\mathrm{LiMn}_{2} \mathrm{O}_{4}$ and changing the electrolyte to aqueous $\mathrm{LiOH} / \mathrm{ZnSO}_{4}$ solution could improve the reversibility; however, due to the high $\mathrm{pH}$ value of the electrolyte, only a few amount of cathode material can be used during charge/discharge processes [23]. Recently, Kang et al. developed a mild zinc ion battery, using $\alpha-\mathrm{MnO}_{2}$ as cathode and $\mathrm{Zn}$ as anode [15], which showed high capacities and a high rate capability. Additionally, a new secondary aqueous $\mathrm{Zn} / \mathrm{LiMn}_{2} \mathrm{O}_{4}$ battery system, namely the rechargeable hybrid aqueous battery (ReHAB) has been developed by our group (Figure 1) [24]. The operation of this battery system is based on two different kinds of redox reactions. At the anode, zinc ions are deposited on the zinc sheet and then dissolved into a mild acidic aqueous solution, containing zinc ions, during charge and discharge processes, respectively. At the cathode, $\mathrm{Li}$ ions are de-intercalated from and intercalated into $\mathrm{LiMn}_{2} \mathrm{O}_{4}$ during charge and discharge processes. The advantages of this battery include the capability of functioning at high rate when the cathode formulation is optimized, and the low cost. Most of the materials used in this battery are commercially available. The battery can be assembled under the atmospheric environment.

Table 1 shows the comparison of various types of major secondary aqueous batteries. Among them, lead-acid batteries have the most widely applications [1]. Compared to lead-acid batteries, our $\mathrm{ReHAB}\left(\mathrm{Zn} / \mathrm{LiMn}_{2} \mathrm{O}_{4}\right.$ batteries) shows about doubled energy density and up to 10 times higher cycle life; and is more environmentally friendly; besides, the cost of our ReHAB is almost the same as lead-acid batteries. However, some technical problems must be solved before the commercialization of the ReHAB. The first problem is the rate capability. The capacity of a standard $10 \mathrm{~kg}$ ReHAB battery should be about $0.6 \mathrm{kWh}$. If it could discharge $100 \%$ of its capacity at $10 \mathrm{C}$ rate (or $6 \mathrm{~min}$ ), the power would be high enough to crank a passenger vehicle [25]. To do this, the ReHAB is required to work at $10 \mathrm{C}$ with the specific discharge capacity of not less than $\sim 100 \mathrm{mAh} \cdot \mathrm{g}^{-1}$. This is accomplished via applying novel carbon materials in the cathode formulation, which is the topic of this review paper. The second problem is the maintenance issue, which we propose to solve by the design of novel thixotropic gel electrolytes [26,27]. The remaining problems are the dendrite formation, corrosion, 
and hydrogen gas evolution on the zinc anode [28,29]. Intensive research efforts based on these issues are under progress. With reasonable high energy density, high power, high safety, and low cost, the ReHAB can be exploited as uninterruptible power supplies, large energy storage devices to interface with the grid, and novel start-stop battery in automobile vehicles.

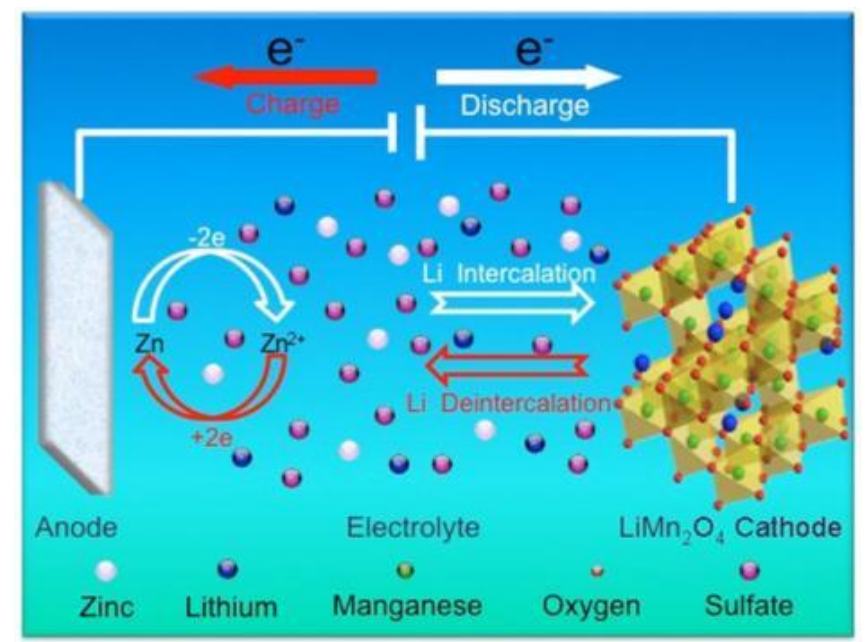

Figure 1. Schematic illustration of the mechanism for ReHAB operation (modified from Ref. [24] with permission from Elsevier).

Table 1. Comparison of various types of major secondary aqueous batteries $[1,3,5,16,24]$.

\begin{tabular}{|c|c|c|c|c|c|}
\hline $\mathrm{X}^{2}$ & Ni-Cd Battery & Ni-MH Battery & $\begin{array}{l}\text { Aqueous Alkali-Metal } \\
\text { Ion Battery }\end{array}$ & $\begin{array}{l}\text { Lead-Acid } \\
\text { Battery }\end{array}$ & $\begin{array}{c}\mathrm{Zn} / \mathrm{LiMn}_{2} \mathrm{O}_{4} \\
\text { Battery }\end{array}$ \\
\hline Working Votage $(\mathrm{V})$ & 1.2 & 1.2 & 1.5 & $1.8-2.0$ & 1.8 \\
\hline Energy Density $\left(\mathrm{Wh} \cdot \mathrm{kg}^{-1}\right)$ & $30-40$ & $70-80$ & $20-60$ & $30-50$ & $50-80$ \\
\hline Power Density $\left(\mathrm{W} \cdot \mathrm{kg}^{-1}\right)$ & $60-90$ & $250-1000$ & - & $250-600$ & $500-800$ \\
\hline Cycle Life & $<550$ & $500-800$ & $>1000$ & $300-500$ & $1000-4000$ \\
\hline Cost $\left(\$ \cdot \mathrm{kW} \cdot \mathrm{h}^{-1}\right)$ & $300-600$ & $350-650$ & - & $30-50$ & $30-50$ \\
\hline
\end{tabular}

\section{Introduction of $\mathrm{LiMn}_{2} \mathrm{O}_{4}$}

Compared with other cathode materials (e.g., $\mathrm{LiCoO}_{2}$ [30-32], $\mathrm{LiNiO}_{2}$ [33], $\mathrm{LiFePO}_{4}$ [34], $\mathrm{NaMnO}_{2}$ [35] and $\mathrm{KMnO}_{2}$ [36]) in aqueous rechargeable batteries, spinel $\mathrm{LiMn}_{2} \mathrm{O}_{4}$ is the most promising cathode material for aqueous rechargeable batteries due to its safety, eco-friendliness, low cost, and excellent structural stability [37]. The crystal structure of spinel $\mathrm{LiMn}_{2} \mathrm{O}_{4}$, space group $F d \overline{3} m$, is illustrated in Figure 2, in which the Li and Mn cations occupied the 8a tetrahedral and the 16d octahedral sites; Li ions transfer in the three-dimensional (3-D) interstitial space provided by the $\mathrm{Mn}_{2} \mathrm{O}_{4}$ framework, which can be expressed by Equations (1) and (2) [38,39].

$$
\begin{gathered}
\mathrm{LiMn}_{2} \mathrm{O}_{4} \rightleftarrows \mathrm{Li}_{0.5} \mathrm{Mn}_{2} \mathrm{O}_{4}+0.5 \mathrm{Li}^{+}+0.5 \mathrm{e}^{-} \\
\mathrm{Li}_{0.5} \mathrm{Mn}_{2} \mathrm{O}_{4} \rightleftarrows 2 \mathrm{MnO}_{2}+0.5 \mathrm{Li}^{+}+0.5 \mathrm{e}^{-}
\end{gathered}
$$




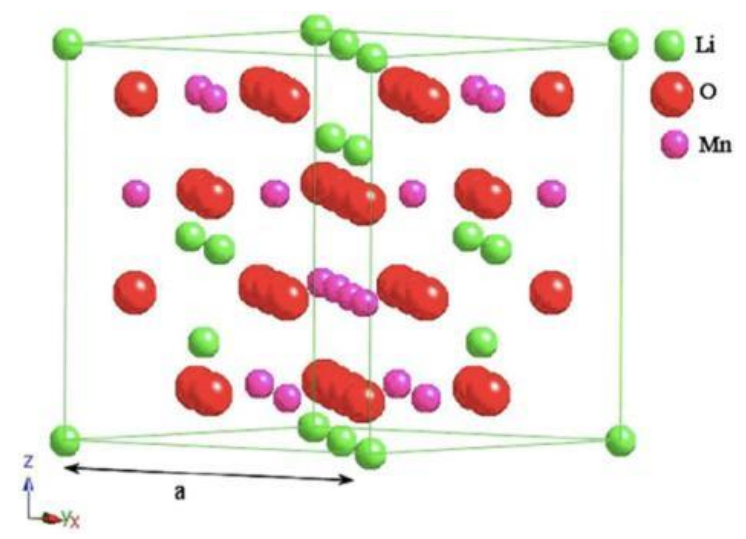

Figure 2. The crystal structure of spinel $\mathrm{LiMn}_{2} \mathrm{O}_{4}$ (reprinted from Ref. [40] with permission from Elsevier).

In 1994, it was reported that $\mathrm{Li}$ ion could de-intercalate/intercalate from/into $\mathrm{LiMn}_{2} \mathrm{O}_{4}$ in aqueous electrolyte for the first time [9]. In the $\mathrm{CV}$ curve of the $\mathrm{LiMn}_{2} \mathrm{O}_{4}$ in the saturated $\mathrm{Li}_{2} \mathrm{SO}_{4}$ solution (Figure 3), two pairs of redox peaks at $0.85 / 0.69 \mathrm{~V}$ and $0.98 / 0.82 \mathrm{~V}$ vs. standard calomel electrode (SCE), respectively, represent the two-step de-intercalation/intercalation of Li ions from/into the tunnels of $\mathrm{LiMn}_{2} \mathrm{O}_{4}$. Besides, the oxidation potentials are much lower than the oxygen generation potential ( $\sim 1.5 \mathrm{~V}$ vs. SCE), revealing the excellent stability of $\mathrm{LiMn}_{2} \mathrm{O}_{4}$ as the cathode for aqueous rechargeable batteries [41].

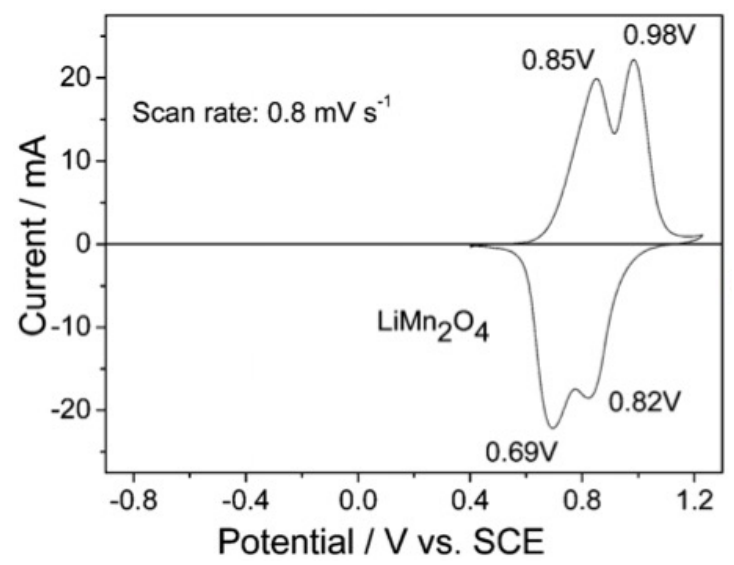

Figure 3. $\mathrm{CV}$ curve of the micrometer $\mathrm{LiMn}_{2} \mathrm{O}_{4}$ in the saturated $\mathrm{Li}_{2} \mathrm{SO}_{4}$ solution (modified from Ref. [41] with permission from Wiley).

However, the dissolution of $\mathrm{Mn}^{3+}$ in acid electrolytes, $\mathrm{Mn}^{3+}{ }_{\text {(solid) }} \rightarrow \mathrm{Mn}^{4+}{ }_{\text {(solid) }}+\mathrm{Mn}^{2+}{ }_{\text {(liquid), and }}$ the phase transition from cubic to tetragonal phase result in the capacity decay, which hindered its practical application $[42,43]$. The dissolution of $\mathrm{Mn}^{3+}$ can be alleviated by surface modification and/or cation doping [38,44-46].

Besides, the rate capability of the $\mathrm{LiMn}_{2} \mathrm{O}_{4}$ cathode is intrinsically low. Specifically, the diffusion of $\mathrm{Li}$ ions and electrons in $\mathrm{LiMn}_{2} \mathrm{O}_{4}$ is slow, leading to the insufficient $\mathrm{Li}$ ion intercalation/de-intercalation under high current density, which cannot satisfy the requirements for energy storage system that can transfer (store or release) energy at high rates [47-49]. Thus, to make the ReHAB capable of working at high rate capability, the development of cathode formulation is one of the most important keys. In this review, we focus on using novel carbon materials, porous graphene and carbon nanotubes (CNTs), as conductive additives to improve the electrical conductivity, thus improving the rate capability of the battery. 


\section{Increase the Electrical Conductivity of $\mathrm{LiMn}_{2} \mathrm{O}_{4}$ Cathode by Adding CNTs or Graphene as Conductive Additive}

\subsection{Increase the Electrical Conductivity of $\mathrm{LiMn}_{2} \mathrm{O}_{4}$ Cathode by Adding CNTs as Conductive Additive}

\subsubsection{Structure, Properties and Synthesis of CNTs}

Since being discovered by Sumio Iijima in 1991 [50], carbon nanotubes (CNTs) have aroused great interest of researchers. CNTs can be envisaged as cylinders rolled by graphene layers (Figure 4). The length of CNTs ranges from $\sim 100 \mathrm{~nm}$ to a few centimeters, while the diameter of the hollow cores changes from less than $1 \mathrm{~nm}$ to $\sim 100 \mathrm{~nm}$, resulting in a high length-to-diameter ratio, or aspect ratio. Based on the number of graphene layers, CNTs can be distinguished into single-walled CNTs (SWNTs) and multi-walled CNTs (MWNTs). SWNTs consist of a single rolled graphene layer, while MWNTs consist of two or more rolled graphene layers [51].

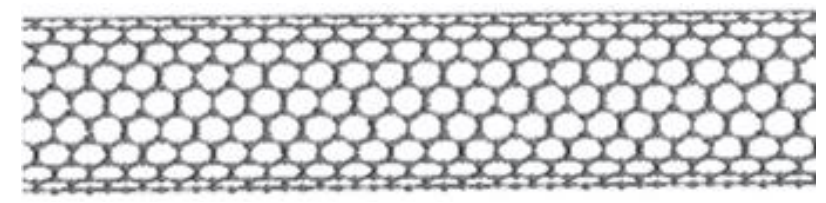

Figure 4. The structural model of carbon nanotube (CNT). (reprinted from Ref. [52] with permission from Elsevier).

CNTs possess unusual properties, including exceptionally high mechanical strength and high electrical conductivity. The bonds of CNTs employ $\mathrm{sp}^{2}$-hybrid carbon atoms, which are stronger than the $\mathrm{sp}^{3}$-hybrid carbon atoms found in diamond, resulting in amazing mechanical strength of CNTs. The free electrons formed $\pi$-electron system, which determines the electronic property; and the one-dimensional (1-D) tube structure facilities the transport of electrons, which contributes to the high electrical conductivity of CNTs. These unique properties make CNTs be widely used in different kinds of applications, such as nanotechnology, energy storage, electronics, gas storage, water filtration, sensors, and so forth [51,52].

Based on the wide application of CNTs, mass production of CNTs with controlled structures becomes urgent. The techniques usually used to prepare CNTs include arc-discharge [50,53], laser ablation [54], gas-phase pyrolysis [55], and chemical vapor deposition (CVD) [56]. Among these methods, CVD has been used to mass-produce CNTs at a low cost. Wei et al. could produce over thousands of tons of CNTs per year by fluidized bed reactor-based CVD method, with the price of MWNTs below US $\$ 100 \mathrm{~kg}^{-1}$ and that of SWNTs below US $\$ 2000 \mathrm{~kg}^{-1}$ [57].

\subsection{2. $\mathrm{LiMn}_{2} \mathrm{O}_{4} / \mathrm{CNT}$ Nanocomposites}

Recently, $\mathrm{LiMn}_{2} \mathrm{O}_{4} / \mathrm{CNT}$ composites have been prepared by the following methods: mechanical alloying method [58], self-assembly process [59], in-situ hydrothermal method by using $\mathrm{MnO}_{2} / \mathrm{CNT}$ and $\mathrm{LiOH}$ as reaction [60-62], microwave-assisted hydrothermal reactions [63,64], spray-deposition method [65] and in-situ hydrothermal growth of binder-free flexible $\mathrm{LiMn}_{2} \mathrm{O}_{4} / \mathrm{CNT}$ composite [63]. These composites have been used in lithium ion batteries as cathode materials, where high electrochemical performances of $\mathrm{LiMn}_{2} \mathrm{O}_{4}$ were attained.

Additionally, $\mathrm{LiMn}_{2} \mathrm{O}_{4} / \mathrm{CNT}$ composites have been used in aqueous rechargeable batteries. Zhang et al. prepared $\mathrm{LiMn}_{2} \mathrm{O}_{4} / \mathrm{MWNTs}$ composite by a ball-milling process with a high temperature treatment at $500{ }^{\circ} \mathrm{C}$ for $1 \mathrm{~h}$ [66], the morphology of the prepared $\mathrm{LiMn}_{2} \mathrm{O}_{4} /$ MWNTs composite is shown in Figure 5a The $\mathrm{LiMn}_{2} \mathrm{O}_{4} / \mathrm{MWNTs}$ cathode was investigated in $1 \mathrm{~mol} \cdot \mathrm{L}^{-1} \mathrm{Li}_{2} \mathrm{SO}_{4}$ for aqueous rechargeable batteries and it delivered higher discharge capacities than the $\mathrm{LiMn}_{2} \mathrm{O}_{4}$ cathode at different current densities (Figure $5 b$ ). Moreover, the results from electrochemical impedance spectroscopy (EIS) revealed that the transfer of $\mathrm{Li}$ ions in the $\mathrm{LiMn}_{2} \mathrm{O}_{4} / \mathrm{MWNTs}$ cathode is much 
faster than that in the $\mathrm{LiMn}_{2} \mathrm{O}_{4}$ cathode. This means that the MWNTs can obviously enhance the capacity storing and the rate capability of the battery. Tang et al. prepared $\mathrm{LiMn}_{2} \mathrm{O}_{4} / \mathrm{CNT}$ composite by a hydrothermal method with a heat treatment at $700{ }^{\circ} \mathrm{C}$ for $8 \mathrm{~h}$, the morphology of the prepared $\mathrm{LiMn}_{2} \mathrm{O}_{4} / \mathrm{CNT}$ composite is shown in Figure $5 \mathrm{c}$ The $\mathrm{LiMn}_{2} \mathrm{O}_{4} / \mathrm{CNT}$ cathode was investigated in $5 \mathrm{~mol} \cdot \mathrm{L}^{-1} \mathrm{LiNO}_{3}$ aqueous electrolyte, and it delivered higher capacities than $\mathrm{LiMn}_{2} \mathrm{O}_{4} /$ active carbon $\left(\mathrm{LiMn}_{2} \mathrm{O}_{4} / \mathrm{AC}\right.$ ) electrode at different current densities (Figure 5d) [61].
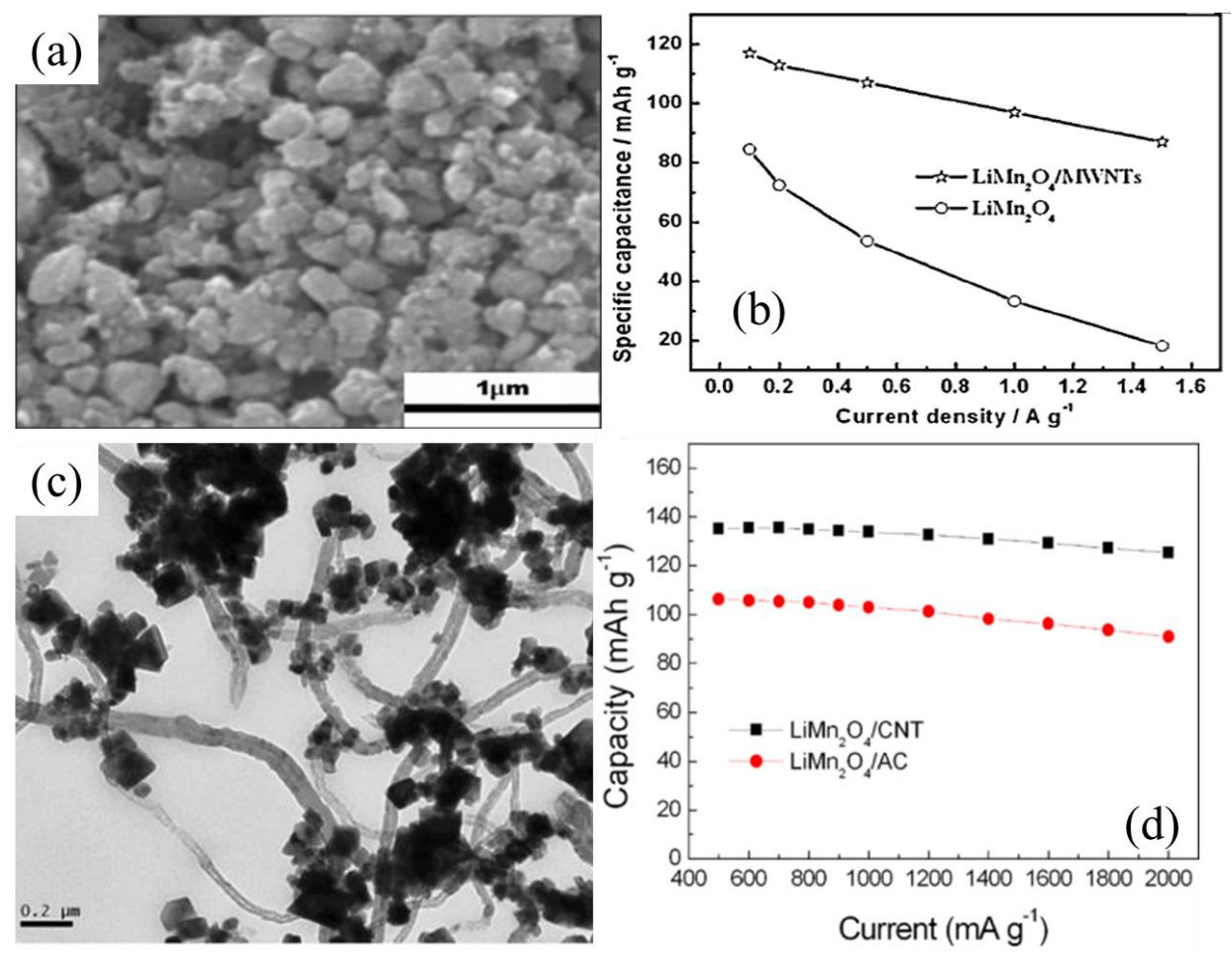

Figure 5. (a) SEM image of as-prepared $\mathrm{LiMn}_{2} \mathrm{O}_{4} / \mathrm{MWNTs}$ composite; (b) rate capability of $\mathrm{LiMn}_{2} \mathrm{O}_{4}$ and $\mathrm{LiMn}_{2} \mathrm{O}_{4} / \mathrm{MWNTs}$ in $1 \mathrm{mo} \cdot \mathrm{L}^{-1} \mathrm{Li}_{2} \mathrm{SO}_{4}$ solution; (c) TEM image of as-synthesized $\mathrm{LiMn}_{2} \mathrm{O}_{4} / \mathrm{CNT}$ nanocomposite by hydrothermal reaction; and (d) rate capability for $\mathrm{LiMn}_{2} \mathrm{O}_{4} / \mathrm{CNT}$ and $\mathrm{LiMn}_{2} \mathrm{O}_{4} / \mathrm{AC}$ composites heat treated at $700{ }^{\circ} \mathrm{C}$ for $8 \mathrm{~h}$ (modified from Ref. [61,66] with permission from Springer and Elsevier).

Besides, Dillon's group developed an aqueous paper battery, using $\mathrm{LiMn}_{2} \mathrm{O}_{4}$ as cathode, carbon coated $\mathrm{TiP}_{2} \mathrm{O}_{7}$ as anode, and carbon nanotube coated paper as current collector in $5 \mathrm{~mol} \cdot \mathrm{L}^{-1} \mathrm{LiNO}_{3}$ solution [67]. Coated by SWNTs not only reduced the resistance of the paper, but also facilitated the penetration of anode and cathode materials into the conductive substrates, resulting in an improved rate capability in comparison with the organic system.

A three-dimensional carbon nanotube/acetylene black (CNT/AB) network was fabricated and used as conductive additive by our group to improve the rate capability of the $\mathrm{LiMn}_{2} \mathrm{O}_{4}$ cathode of the rechargeable aqueous $\mathrm{Zn} / \mathrm{LiMn}_{2} \mathrm{O}_{4}$ battery system, or ReHAB, using a simple mechanical mixing approach [68]. Figure 6a shows the schematic structure of hierarchical CNT/AB/LiMn $2 \mathrm{O}_{4}$ electrodes. The small black dots represent $\mathrm{AB}$ nanoparticles, the brown squares represent $\mathrm{LiMn}_{2} \mathrm{O}_{4}$ nanoparticles, and the blue lines represent CNTs. The morphology of the $\mathrm{CNT} / \mathrm{AB} / \mathrm{LiMn}_{2} \mathrm{O}_{4}$ electrode can also be confirmed by SEM (Figure 6b) and TEM (Figure $6 \mathrm{c}$ ) images. The CNTs, prepared by a chemical vapor deposition method, show $\sim 100 \mu \mathrm{m}$ in length and $\sim 11 \mathrm{~nm}$ in diameter, which can provide long-range conductive pathways for fast electron transfer. Herein, the CNT/AB/LiMn $\mathrm{O}_{4}$ electrode (CNT:AB $=1: 2$, wt \%) shows an excellent rate capability (a specific capacity of $105 \mathrm{mAh} \cdot \mathrm{g}^{-1}$ at $10 \mathrm{C}, 1 \mathrm{C}=120 \mathrm{mAh} \cdot \mathrm{g}^{-1}$, Figure $\left.6 \mathrm{~d}\right)$. 

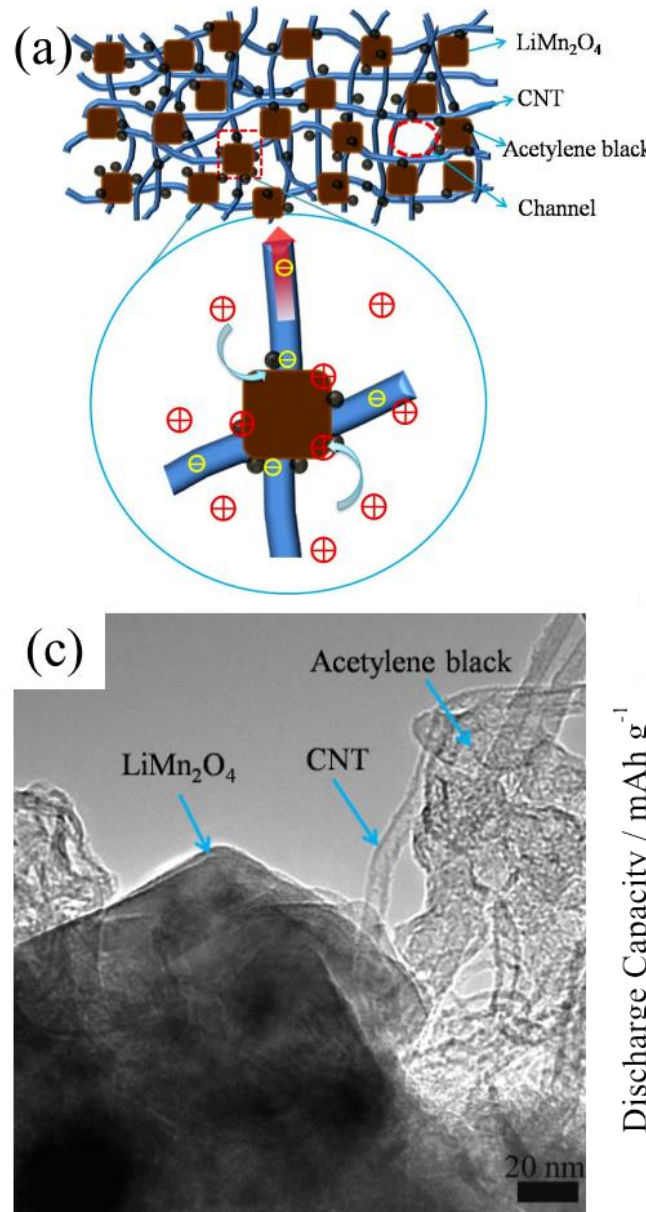

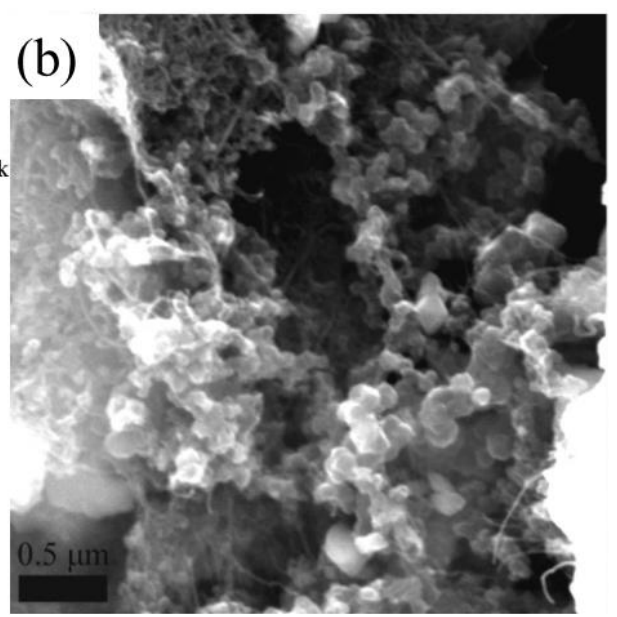

(d)

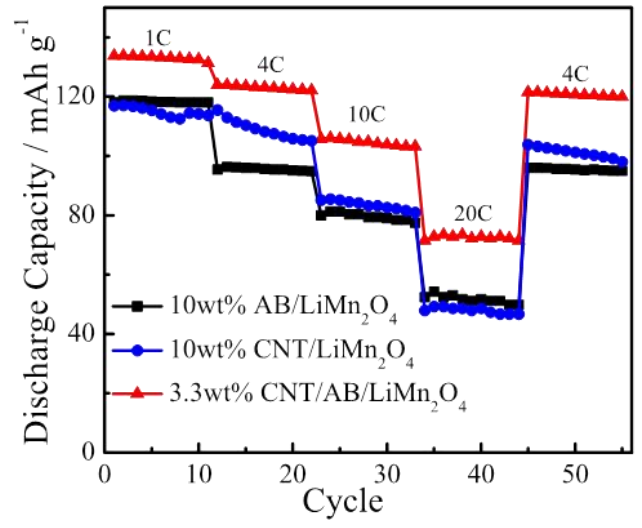

Figure 6. (a) Schematic illustration of CNT/AB/ $\mathrm{LiMn}_{2} \mathrm{O}_{4}$ electrode; (b) SEM; and (c) TEM images of the $3.3 \mathrm{wt} \% \mathrm{CNT} / \mathrm{AB} / \mathrm{LiMn}_{2} \mathrm{O}_{4}$ electrode; and (d) rate capability of the $3.3 \mathrm{wt} \% \mathrm{CNT} / \mathrm{AB} / \mathrm{LiMn}_{2} \mathrm{O}_{4}$, $10 \mathrm{wt} \% \mathrm{CNT} / \mathrm{LiMn}_{2} \mathrm{O}_{4}$, and $10 \mathrm{wt} \% \mathrm{AB} / \mathrm{LiMn}_{2} \mathrm{O}_{4}$ electrodes (modified from Ref. [68] with permission from Springer).

Additionally, a binder-free flexible $\mathrm{LiMn}_{2} \mathrm{O}_{4} / \mathrm{CNT}$ hybrid film was prepared by our group (Figure 7a) and used as a high power cathode for the ReHAB [69]. LiMn ${ }_{2} \mathrm{O}_{4}$ particles and CNTs are highly entangled together (Figure $7 b$ ) to form a free-standing hybrid film with a high mechanical strength (Figure 7c,d) and a good conductivity which facilitate the transfer of electrons. Herein, the $\mathrm{LiMn}_{2} \mathrm{O}_{4} / \mathrm{CNT}$ electrode exhibits an excellent rate capability (a specific capacity of $100 \mathrm{mAh} \cdot \mathrm{g}^{-1}$ at $10 \mathrm{C}, 1 \mathrm{C}=120 \mathrm{mAh} \cdot \mathrm{g}^{-1}$, Figure 7e). While, the Van Der Waals forces between $\mathrm{LiMn}_{2} \mathrm{O}_{4}$ nanoparticles and CNTs are weak and these bonding may get weaken during cycling, which results in the minor decrease of capacity (Figure 7f) [70]. It is worth mentioning that this is the first demonstration of using highly stable binder-free flexible $\mathrm{LiMn}_{2} \mathrm{O}_{4} / \mathrm{CNT}$ electrodes in aqueous rechargeable battery. 

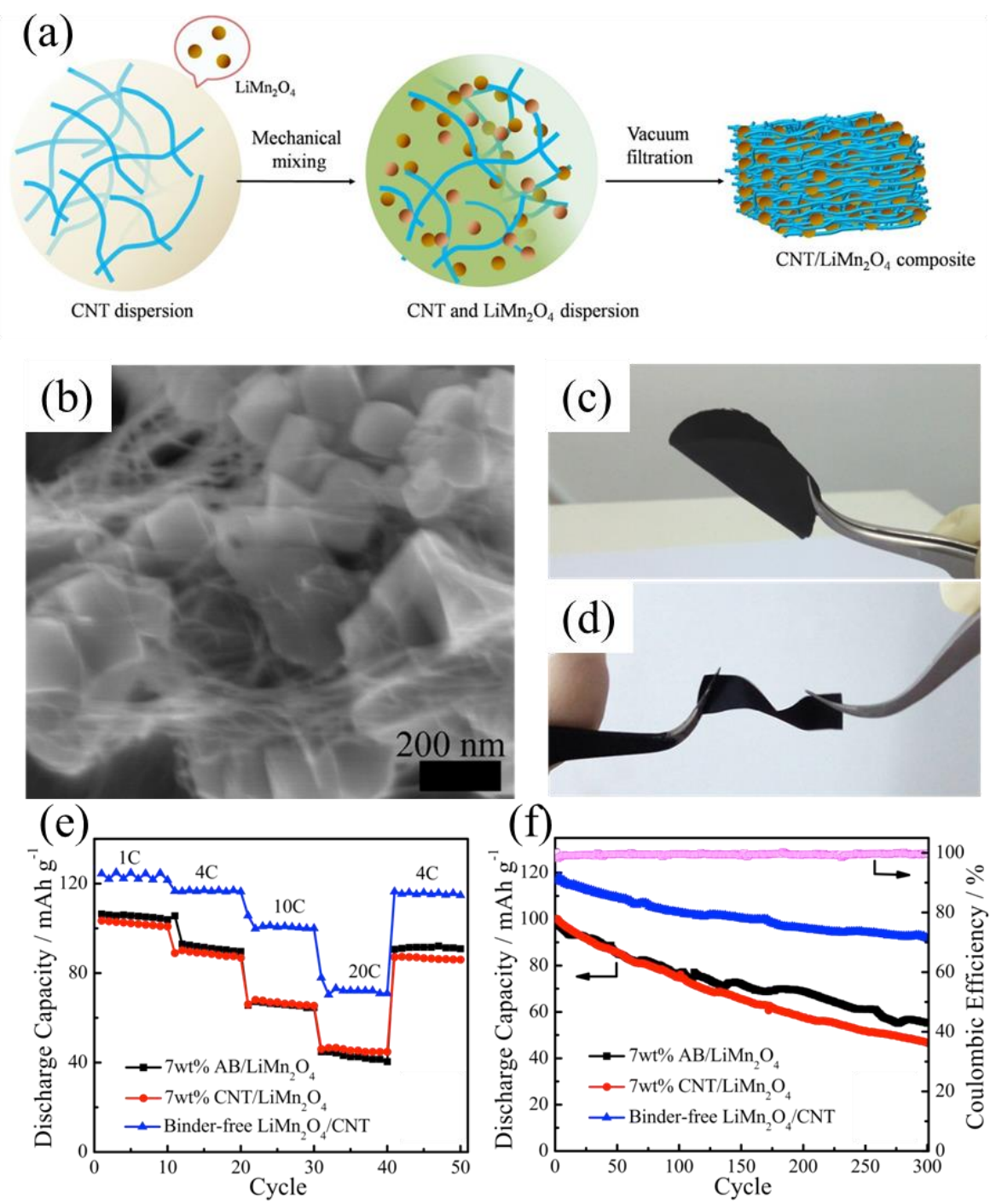

Figure 7. (a) Schematic fabrication of binder-free flexible $\mathrm{LiMn}_{2} \mathrm{O}_{4} / \mathrm{CNT}$ network electrodes through dispersion and vacuum filtration processes; (b) SEM image of the binder-free flexible $\mathrm{LiMn}_{2} \mathrm{O}_{4} / \mathrm{CNT}$ electrode; optical photographs of the produced hybrid film under: (c) bending; and (d) twisting; and comparison of: (e) rate; and (f) cycling performance of the binder-free $\mathrm{LiMn}_{2} \mathrm{O}_{4} / \mathrm{CNT}, 7$ wt \% $\mathrm{CNT} / \mathrm{LiMn}_{2} \mathrm{O}_{4}$, and $7 \mathrm{wt} \% \mathrm{AB} / \mathrm{LiMn}_{2} \mathrm{O}_{4}$ electrodes (modified from Ref. [69] with permission from Elsevier).

\subsection{Increase the Electrical Conductivity of $\mathrm{LiMn}_{2} \mathrm{O}_{4}$ Cathode by Adding Graphene as Conductive Additive}

\subsubsection{Structure, Properties and Synthesis of Graphene}

Since being discovered by Geim in 2004, graphene has caused widespread concerns of scientists. Graphene, a two-dimensional (2-D) monolayer graphite sheet of $\mathrm{sp}^{2}$ carbon atoms with a honeycomb structure, has a large specific surface area of $2630 \mathrm{~m}^{2} \cdot \mathrm{g}^{-1}$ [71,72]. It is considered as the fundamental structural units, which can be wrapped into zero-dimensional (0-D) fullerene, rolled into 1-D CNTs, and stacked into three-dimensional (3-D) graphite, as shown in Figure 8. 


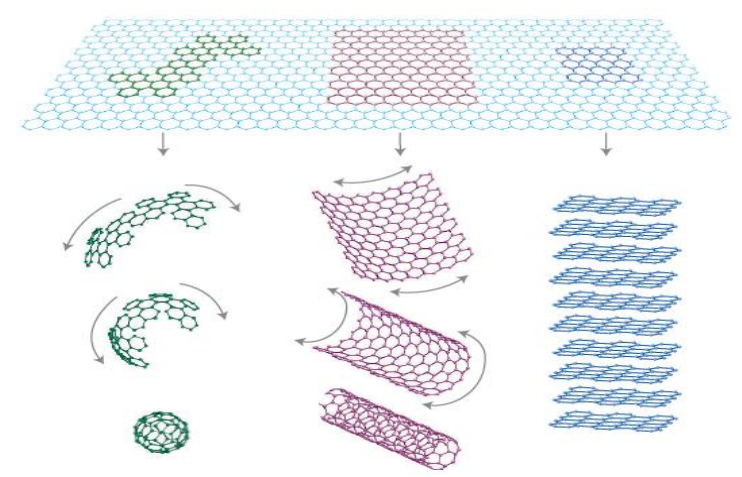

Figure 8. Graphene is the fundamental structural units for other carbonaceous materials (0-D fullerenes, 1-D CNTs and 3-D graphite) (reprinted from Ref. [72] with permission from Nature Publishing Group).

Graphene possesses unique mechanical and thermal properties. The intrinsic tensile strength of graphene is up to $130 \mathrm{GPa}$, which makes it the strongest material [73]. The thermal conductivity of graphene is up to $5300 \mathrm{~W} \cdot(\mathrm{m} \cdot \mathrm{K})^{-1}$, which is four times of the diamond [74]. Moreover, the highly special electrical properties of graphene attract much more attentions of researchers: the giant intrinsic mobility of which is up to $15,000 \mathrm{~cm}^{2} \cdot(\mathrm{V} \cdot \mathrm{s})^{-1}$ [75]; the velocity of electrons in which is three hundredth of the speed of light, exceeding most of conductors [76]. All of these electrical properties contribute to the best conductivity of graphene. Graphene is expected to be widely used in different kinds of fields, such as energy storage, nanotechnology, electronic devices, biomedical materials, and so forth $[71,77,78]$.

Currently, there are usually six different methods to prepare graphene: mechanical exfoliation [79], graphene oxide (GO) reduction [80], CVD [81,82], epitaxial growth [83], cutting carbon nanotubes [84], direct sonication and chemical reduction [85]. Among these methods, only GO reduction method and CVD method are suitable for large-scale graphene production.

Li et al. [86] reported the preparation of graphene through a GO reduction method, which includes three steps as following (Figure 9): (1) oxidize graphite to hydrophilic GO with greater interlayer distance by modified Hummers' method; (2) disperse GO in water with ultra-sonication to form GO colloids; (3) convert the insulated GO back to conducted graphene by chemical reduction, for example, using hydrazine. The graphene prepared by the GO reduction method is named as reduced graphene oxide (RGO). The graphene oxide reduction method has inevitable disadvantages: the structure of graphene is destroyed by strong oxidant and reductant used in the preparation process, compromising the electrochemical performance of RGO; besides, graphene oxide is easily accumulated in aqueous solution due to the van der Waals force. However, this method is of low cost and is suitable to prepare graphene derivatives, which expands the application of graphene.

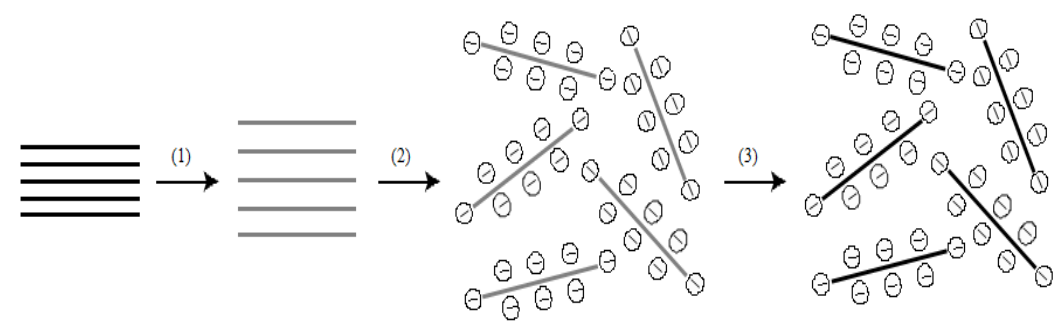

Figure 9. Schematic illustration of the synthesis of reduced graphene oxide dispersions. (1) Graphite (black blocks) is oxidized to graphite oxide (lighter colored blocks) with greater interlayer distance by a modified Hummers' method; (2) Graphite oxide is dispersed in water with an ultra-sonication agitation to form GO colloids; and (3) GO colloids are reduced to reduced graphene oxide (RGO) by hydrazine (reprinted from Ref. [86] with permission from Nature Publishing Group). 
The CVD method provides a promising way to realize the controllable preparation of graphene [82]. Graphene with different properties can be obtained by selecting different substrates and carbonaceous sources, as well as controlling reaction temperature in the preparation process. Typically, the substrate (including metal substrates such as $\mathrm{Fe}, \mathrm{Co}, \mathrm{Ni}, \mathrm{Cu}$, etc., and nonmetal substrates such as $\mathrm{CuO}, \mathrm{NiO}$, etc.) is exposed to the volatile precursors (usually carbon sources such as acetylene, ethylene, methane, etc.), which cracked at high temperature to form desired deposit on the surface of the substrate. Generally, volatile by-products produced in the CVD process flow out through the reactor. After the substrate is removed, the desired product is obtained.

The ability to form $\mathrm{sp}^{2}$ crystalline carbon from solid solutions of various transition metals (e.g., $\mathrm{Fe}, \mathrm{Co}, \mathrm{Ni}$, and $\mathrm{Cu}$ ) is determined by their carbon affinity [87]. In the case of $\mathrm{Fe}$, the asymmetrical distribution of electrons in the $d$-shell $\left\{[\mathrm{Ar}] 3 \mathrm{~d}^{6} 4 \mathrm{~s}^{2}\right\}$ leads to mutual repulsion, which results in its higher affinity towards carbon [88]; the high affinity between Fe and $\mathrm{C}$ makes it more favorable to form carbide than graphitic carbon. $\mathrm{Cu}$ has the lowest affinity to carbon $[89,90]$ and has very low carbon solubility compared to $\mathrm{Co}$ and $\mathrm{Ni}\left(0.001-0.008 \mathrm{wt} \%\right.$ at $\sim 1084{ }^{\circ} \mathrm{C}$ for $\mathrm{Cu}[90,91], \sim 0.6 \mathrm{wt} \%$ for $\mathrm{Ni}$ at $\sim 1326{ }^{\circ} \mathrm{C}$, and $\sim 0.9 \mathrm{wt} \%$ for $\mathrm{Co}$ at $\sim 1320^{\circ} \mathrm{C}$ ) [92], which can owe to the fully filled 3d-electron shell $\left\{[\mathrm{Ar}] 3 \mathrm{~d}^{10} 4 \mathrm{~s}^{1}\right\}$ structure of $\mathrm{Cu}$, the most stable configuration; hence, $\mathrm{Cu}$ can only form soft bonds with carbon via charge transfer from the $\mathrm{p}$ electrons in the $\mathrm{sp}^{2}$ hybridized carbon to the empty $4 \mathrm{~s}$ states of $\mathrm{Cu}[88,93]$. Therefore, the very low affinity between carbon and $\mathrm{Cu}$ along with the ability to form intermediate soft bonds makes copper the most suitable catalyst for graphitic carbon formation.

Ning et al. prepared a kind of porous graphene, or PG, by CVD method, using porous $\mathrm{MgO}$ as substrates. Figure 10 shows the two-step preparation process of $\mathrm{PG}$, synthesis of porous $\mathrm{MgO}$ layers and template growth of PG [82]. Firstly, $\mathrm{MgO}$ powder was mixed with deionized water under super-ultrasonic stirring. The mixture was boiled in a reflux apparatus for $24 \mathrm{~h}$. After filtration, drying, and calcination at $500{ }^{\circ} \mathrm{C}$ for $30 \mathrm{~min}$, porous $\mathrm{MgO}$ layers were obtained. Then, PG was prepared by a one-step CVD process, in which $\mathrm{CH}_{4}$ was cracked at $875^{\circ} \mathrm{C}$ to create carbon deposits on the $\mathrm{MgO}$ templates, after removing $\mathrm{MgO}$ by an acid washing process and drying at $80^{\circ} \mathrm{C}$ for $12 \mathrm{~h}$, PG was finally obtained.

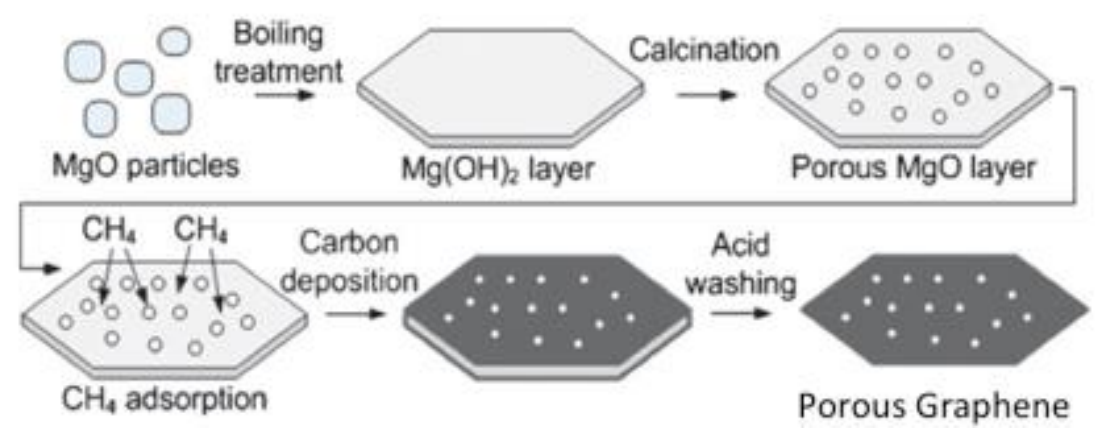

Figure 10. Schematic illustration of the preparation of porous graphene (modified from Ref. [82] with permission from Royal Society of Chemistry).

\subsection{2. $\mathrm{LiMn}_{2} \mathrm{O}_{4} /$ Graphene Nanocomposites}

Except for CNTs, graphene, a 2-D single layer of carbon atoms, possesses unique properties such as high surface area and superior electrical conductivity [94]. The high surface area can increase the interfacial contact between electrode and electrolyte, resulting in a fast transportation of Li ions; the superior electrical conductivity contributes to a fast electron transport. Therefore, graphene can also be used as an ideal conductive additive to improve the electrochemical performance of $\mathrm{LiMn}_{2} \mathrm{O}_{4}$ cathode $[59,95,96]$. Recently, $\mathrm{LiMn}_{2} \mathrm{O}_{4} /$ graphene $[97,98]$ and $\mathrm{LiMn}_{2} \mathrm{O}_{4} / \mathrm{RGO}[99,100]$ composites have been prepared and studied as the cathodes of lithium ion batteries, resulting into highly improved rate capabilities. 
Additionally, there are a few reports about using graphene in aqueous rechargeable battery [97,101-103]. Jiang et al. used reduced graphene oxide (RGO) nanosheets (inserted figure of Figure 11a) as conductive additive to improve the rate capability of the $\mathrm{LiMn}_{2} \mathrm{O}_{4}$ cathode. The electrochemical measurements were conducted in $5 \mathrm{~mol} \cdot \mathrm{L}^{-1} \mathrm{LiNO}_{3}$ aqueous electrolyte. When RGO nanosheets and acetylene black $(\mathrm{AB})$ nanoparticles co-existed with the weight ratio of 1:2 (the content of RGO is $5 \mathrm{wt} \%$, Figure 11a) in the electrode, the rate performance of the $\mathrm{LiMn}_{2} \mathrm{O}_{4}$ electrode was highly enhanced (Figure 11b). The effective conducting pathways formed by RGO nanosheets and acetylene black nanoparticles contribute to the high rate capability [97].
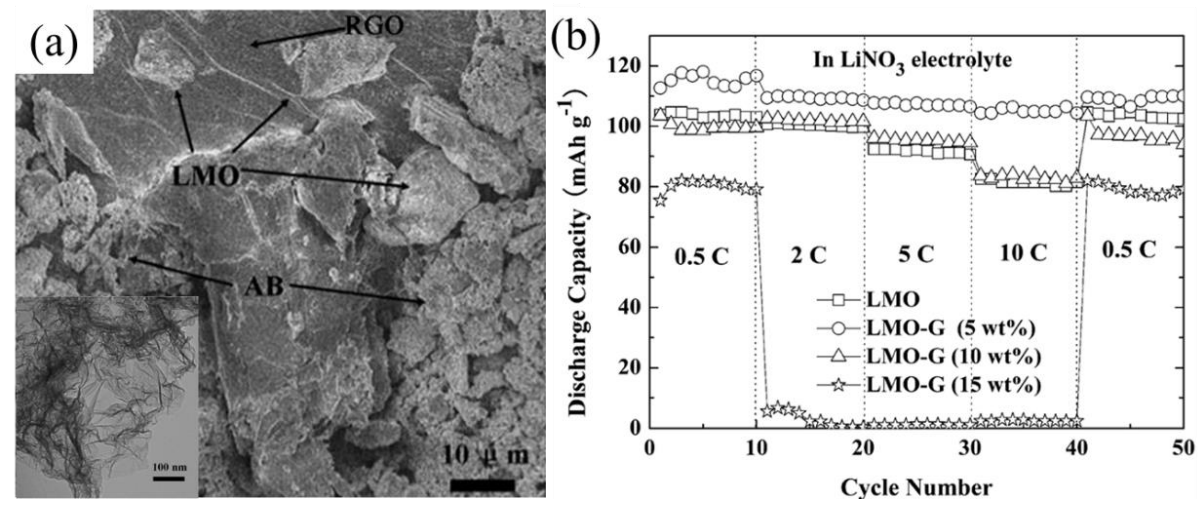

Figure 11. (a) SEM image of the $\mathrm{LiMn}_{2} \mathrm{O}_{4}-\mathrm{RGO}(5 \mathrm{wt} \%$ ), inserted figure shows the TEM image of the RGO; and (b) galvanostatic charge/discharge curves of $\mathrm{LiMn}_{2} \mathrm{O}_{4}-\mathrm{RGO}(5 \mathrm{wt} \%$ ) at various C-rates (modified from Ref. [97] with permission from Royal Society of Chemistry).

Besides, PG was prepared and directly used in our ReHAB as conductive additive in the $\mathrm{LiMn}_{2} \mathrm{O}_{4}$ cathode [104]. The PG can provide facile access for the electrolyte and high electrical conductivity for the cathode. When mixed with AB with the weight ratio of 1:2 (the content of PG is $3.3 \mathrm{wt} \%$ ) in the electrode, it also shows a higher rate capability (a specific capacity of $94 \mathrm{mAh} \cdot \mathrm{g}^{-1}$ at $10 \mathrm{C}$, $\left.1 \mathrm{C}=120 \mathrm{mAh} \cdot \mathrm{g}^{-1}\right)$, which is comparable to the results of Jiang et al.

\subsection{Comparison of Different Conductive Additives in LiMn ${ }_{2} \mathrm{O}_{4}$ Cathodes in Aqueous Batteries}

The electrochemical performances of $\mathrm{LiMn}_{2} \mathrm{O}_{4}$ cathodes with different conductive additives in aqueous batteries are listed in Table 2. It shows that better rate capability can be achieved by using CNTs as conductive additive than graphene. Among which, the $3.3 \mathrm{wt} \% \mathrm{CNT} / \mathrm{AB} / \mathrm{LiMn}_{2} \mathrm{O}_{4}$ and binder-free flexible $\mathrm{LiMn}_{2} \mathrm{O}_{4} / \mathrm{CNT}$ electrodes prepared by our group both exhibit high rate capability, which attributes to the long-range conductivity provided by CNTs. Although $\mathrm{LiMn}_{2} \mathrm{O}_{4} / \mathrm{CNT}$ composite [61] prepared by a hydrothermal method shows a higher capacity than our electrodes, its content of conductive additive is as high as $\sim 33 \mathrm{wt} \%$, including $\sim 13 \mathrm{wt} \%$ CNTs and $20 \mathrm{wt} \%$ acetylene black, while, for our electrodes, the content of conductive additive is only $10 \mathrm{wt} \%$, especially for the $3.3 \mathrm{wt} \% \mathrm{CNT} / \mathrm{AB} / \mathrm{LiMn}_{2} \mathrm{O}_{4}$ electrode, only $3.3 \mathrm{wt} \% \mathrm{CNTs}$ was used. Besides, the $3.3 \mathrm{wt} \%$ $\mathrm{CNT} / \mathrm{AB} / \mathrm{LiMn}_{2} \mathrm{O}_{4}$ electrode was prepared by a simple mechanical mixing method, which is very simple and feasible to large scale industry applications. Compared to the $3.3 \mathrm{wt} \% \mathrm{CNT} / \mathrm{AB} / \mathrm{LiMn}_{2} \mathrm{O}_{4}$ electrode, the $3.3 \mathrm{wt} \% \mathrm{PG} / \mathrm{AB} / \mathrm{LiMn}_{2} \mathrm{O}_{4}$ electrode prepared by the same mechanical mixing method shows a much better cycling performance ( $17 \%$ higher capacity retention after 300 cycles at $4 \mathrm{C})$.

Table 3 compares the properties of different conductive additives, AB, CNTs, and PG, used in the formulation of the $\mathrm{LiMn}_{2} \mathrm{O}_{4}$ cathode in the ReHAB. Compared to $\mathrm{AB}, \mathrm{CNTs}$ can provide long-range conductivity; PG with a large surface area can provide a large conducting contact area between $\mathrm{LiMn}_{2} \mathrm{O}_{4}$ and conducting pathways. However, for CNTs, the reaction between CNTs and Li ions during cycling processes makes them more fragile, so they may break into shorter lengths with the 
volume changes of the active materials, resulting in the destroy of the long-range conductivity, thus the decrease of capacity [51]; for the PG, the high cost hinders its large-scale application.

Table 2. Comparison of different conductive additives in $\mathrm{LiMn}_{2} \mathrm{O}_{4}$ cathodes in aqueous batteries.

\begin{tabular}{ccccc}
\hline Cathode & $\begin{array}{c}\text { Specific Capacity } \\
\text { at } \mathbf{4} \mathbf{C}\left(\mathbf{m A h} \cdot \mathbf{g}^{-1}\right)\end{array}$ & $\begin{array}{c}\text { Specific Capacity } \\
\text { at } \mathbf{1 0 ~} \mathbf{~}\left(\mathbf{m A h} \cdot \mathbf{g}^{-\mathbf{1}}\right)\end{array}$ & $\begin{array}{c}\text { Cycling } \\
\text { Performance }\end{array}$ & Reference \\
\hline $\mathrm{LiMn}_{2} \mathrm{O}_{4} / \mathrm{MWNTs}$ & 110 & 90 & $1000(93 \%)$ & {$[66]$} \\
$\mathrm{LiMn} \mathrm{O}_{4} / \mathrm{CNT}$ & 136 & 130 & $2000(72 \%)$ & {$[61]$} \\
$3.3 \mathrm{wt} \% \mathrm{CNT} / \mathrm{AB} / \mathrm{LiMn}_{2} \mathrm{O}_{4}$ & 125 & 105 & $300(70 \%)$ & {$[68]$} \\
$\mathrm{Binder-free} \mathrm{flexible} \mathrm{LiMn} \mathrm{O}_{4} / \mathrm{CNT}$ & 120 & 100 & $300(80 \%)$ & {$[69]$} \\
$\mathrm{LiMn} \mathrm{O}_{4}-\mathrm{RGO}(5 \mathrm{wt} \%)$ & 107 & 105 & $100(88 \%)$ & {$[97]$} \\
$3.3 \mathrm{wt} \% \mathrm{PG} / \mathrm{AB} / \mathrm{LiMn}_{2} \mathrm{O}_{4}$ & 110 & 94 & $300(87 \%)$ & {$[104]$} \\
\hline
\end{tabular}

NOTE: MWNTs: Multi-walled Carbon Nanotubes; AB: Acetylene Black; CNTs: Carbon Nanotubes; PG: Porous Graphene; RGO: Reduced Graphene Oxide.

Table 3. Comparison of different conductive additives in $\mathrm{LiMn}_{2} \mathrm{O}_{4}$ cathode of the $\mathrm{ReHAB}$ [104].

\begin{tabular}{cccc}
\hline $\begin{array}{c}\text { Conductive } \\
\text { Additive }\end{array}$ & $\begin{array}{c}\text { Specific Surface Area } \\
\left(\mathbf{m}^{\mathbf{2}} \cdot \mathbf{g}^{-\mathbf{1}}\right)\end{array}$ & Conducting Mode & Price (US: $\left.\mathbf{\$} \cdot \mathbf{k g}^{\mathbf{- 1}}\right)$ \\
\hline $\mathrm{AB}$ & $50-70$ & Point-to-point & 30 \\
$\mathrm{CNTs}$ & $200-300$ & Point-to-line & 100 \\
PG & $1100-1200$ & Point-to-plane & 3000 \\
\hline NOTE: AB: Acetylene Black; CNTs: Carbon Nanotubes; PG: Porous Graphene.
\end{tabular}

\section{Conclusions}

This paper gives a review of exploiting CNTs and porous graphene as conductive additives to improve the rate capability of $\mathrm{LiMn}_{2} \mathrm{O}_{4}$ cathode in the rechargeable aqueous $\mathrm{Zn} / \mathrm{LiMn}_{2} \mathrm{O}_{4}$ battery, namely the ReHAB. CNTs can provide stable and long-range conducting network, so they can be used as an ideal conductive additive to improve electrical conductivity of battery electrodes. In addition to CNTs, porous graphene with an abundant porous structure, a high surface area, and an excellent electrical conductivity, was used as a conductive additive to the $\mathrm{LiMn}_{2} \mathrm{O}_{4}$ cathode for the first time, resulting in highly improved electrochemical performance of the $\mathrm{LiMn}_{2} \mathrm{O}_{4}$ cathode.

CNTs and graphene can highly improve the rate capability of the ReHAB by simple mechanical mixing. Compared to CNTs, $\mathrm{LiMn}_{2} \mathrm{O}_{4}$ cathode with porous graphene as conductive additive shows much better cycling stability; however, mass production of porous graphene with high quality at a much lower price is still the main problem that hinders its large-scale application; besides, systematic studies of deposition/dissolution rate of zinc at the anode are needed to eliminate its influence on the Li ion diffusion.

Although many obstacles still need to be overcome before the commercialization of the ReHAB, major advances in both performance enhancement and mechanism elucidation of the ReHAB have been reported. It is believed that further investigation will eventually lead to the practical application of the ReHAB in the near future.

Acknowledgments: This research was financially supported by Positec (No. 2100-500-105-2974-121701), the Natural Sciences and Engineering Research Council of Canada (NSERC, No. 216990), Canadian Foundation for Innovation (CFI, No. 202335), the Canada Research Chairs (CRC, No. 211464) program and Mitacs (Nos. IT04444 and IT06145). One of the authors (Xiao Zhu) thanks the China Scholarship Council for Study Abroad Scholarship (No. 201306440001).

Author Contributions: Xiao Zhu wrote the paper; Tuan K. A. Hoang and Pu Chen provided peer review of paper; and $\mathrm{Pu}$ Chen provided academic research supervision.

Conflicts of Interest: The authors declare no conflict of interest. 


\section{References}

1. Soloveichik, G.L. Battery technologies for large-scale stationary energy storage. Annu. Rev. Chem. Biomol. 2011, 2, 503-527. [CrossRef] [PubMed]

2. Wang, F.; Xiao, S.; Hou, Y.; Hu, C.; Liu, L.; Wu, Y. Electrode materials for aqueous asymmetric supercapacitors. RSC Adv. 2013, 3, 13059. [CrossRef]

3. Alias, N.; Mohamad, A.A. Advances of aqueous rechargeable lithium-ion battery: A review. J. Power Sources 2015, 274, 237-251. [CrossRef]

4. Shen, Y.; Kordesch, K. The mechanism of capacity fade of rechargeable alkaline manganese dioxide zinc cells. J. Power Sources 2000, 87, 162-166. [CrossRef]

5. Shukla, A.; Venugopalan, S.; Hariprakash, B. Nickel-based rechargeable batteries. J. Power Sources 2001, 100, 125-148. [CrossRef]

6. Köhler, U.; Antonius, C.; Bäuerlein, P. Advances in alkaline batteries. J. Power Sources 2004, 127, 45-52. [CrossRef]

7. Wang, H.; Liang, Y.; Gong, M.; Li, Y.; Chang, W.; Mefford, T.; Zhou, J.; Wang, J.; Regier, T.; Wei, F. An ultrafast nickel-iron battery from strongly coupled inorganic nanoparticle/nanocarbon hybrid materials. Nat. Commun. 2012, 3, 917. [CrossRef] [PubMed]

8. Gao, X.P.; Yao, S.M.; Yan, T.Y.; Zhou, Z. Alkaline rechargeable Ni/Co batteries: Cobalt hydroxides as negative electrode materials. Energy Environ. Sci. 2009, 2, 502-505. [CrossRef]

9. Li, W.; Dahn, J.; Wainwright, D. Rechargeable lithium batteries with aqueous electrolytes. Science 1994, 264, 1115-1118. [CrossRef] [PubMed]

10. Wang, G.; Fu, L.; Zhao, N.; Yang, L.; Wu, Y.; Wu, H. An aqueous rechargeable lithium battery with good cycling performance. Angew. Chem. Int. Ed. 2007, 119, 299-301. [CrossRef]

11. Wang, H.; Huang, K.; Zeng, Y.; Yang, S.; Chen, L. Electrochemical properties of $\mathrm{TiP}_{2} \mathrm{O}_{7}$ and $\mathrm{LiTi}_{2}\left(\mathrm{PO}_{4}\right)_{3}$ as anode material for lithium ion battery with aqueous solution electrolyte. Electrochim. Acta 2007, 52, 3280-3285. [CrossRef]

12. Luo, J.Y.; Cui, W.J.; He, P.; Xia, Y.Y. Raising the cycling stability of aqueous lithium-ion batteries by eliminating oxygen in the electrolyte. Nat. Chem. 2010, 2, 760-765. [CrossRef] [PubMed]

13. Wang, X.; Hou, Y.; Zhu, Y.; Wu, Y.; Holze, R. An aqueous rechargeable lithium battery using coated Li metal as anode. Sci. Rep. 2013, 3, 1401. [CrossRef] [PubMed]

14. Pasta, M.; Wessells, C.D.; Huggins, R.A.; Cui, Y. A high-rate and long cycle life aqueous electrolyte battery for grid-scale energy storage. Nat. Commun. 2012, 3, 1149. [CrossRef] [PubMed]

15. Xu, C.; Li, B.; Du, H.; Kang, F. Energetic zinc ion chemistry: The rechargeable zinc ion battery. Angew. Chem. Int. Ed. 2012, 124, 957-959. [CrossRef]

16. Whitacre, J.; Tevar, A.; Sharma, $\mathrm{S} . \mathrm{Na}_{4} \mathrm{Mn}_{9} \mathrm{O}_{18}$ as a positive electrode material for an aqueous electrolyte sodium-ion energy storage device. Electrochem. Commun. 2010, 12, 463-466. [CrossRef]

17. Park, S.I.; Gocheva, I.; Okada, S.; Yamaki, J.I. Electrochemical properties of $\mathrm{NaTi}_{2}\left(\mathrm{PO}_{4}\right)_{3}$ anode for rechargeable aqueous sodium-ion batteries. J. Electrochem. Soc. 2011, 158, A1067-A1070. [CrossRef]

18. Wu, W.; Mohamed, A.; Whitacre, J.F. Microwave synthesized $\mathrm{NaTi}_{2}\left(\mathrm{PO}_{4}\right)_{3}$ anode materials for rechargeable aqueous electrolyte sodium-ion battery. In Meeting Abstracts; Electrochemical Society (ECS): Pennington, NJ, USA, 2012; Volume 15, p. 1859.

19. Li, Z.; Young, D.; Xiang, K.; Carter, W.C.; Chiang, Y.M. Towards high power high energy aqueous sodium ion batteries: The $\mathrm{NaTi}_{2}\left(\mathrm{PO}_{4}\right)_{3} / \mathrm{Na}_{0.44} \mathrm{MnO}_{2}$ System. Adv. Energy Mater. 2013, 3, 290-294. [CrossRef]

20. Wessells, C.D.; Huggins, R.A.; Cui, Y. Copper hexacyanoferrate battery electrodes with long cycle life and high power. Nat. Commun. 2011, 2, 550. [CrossRef] [PubMed]

21. Chen, L.; Gu, Q.; Zhou, X.; Lee, S.; Xia, Y.; Liu, Z. New-concept batteries based on aqueous $\mathrm{Li}^{+} / \mathrm{Na}^{+}$ mixed-ion electrolytes. Sci. Rep. 2013, 3, 1946. [CrossRef] [PubMed]

22. Wessells, C.D.; Peddada, S.V.; McDowell, M.T.; Huggins, R.A.; Cui, Y. The effect of insertion species on nanostructured open framework hexacyanoferrate battery electrodes. J. Electrochem. Soc. 2012, 159, A98. [CrossRef]

23. Minakshi, M.; Singh, P.; Thurgate, S.; Prince, K. Electrochemical behavior of olivine-type $\mathrm{LiMnPO}_{4}$ in aqueous solutions. Electrochem. Solid-State Lett. 2006, 9, A471-A474. [CrossRef] 
24. Yan, J.; Wang, J.; Liu, H.; Bakenov, Z.; Gosselink, D.; Chen, P. Rechargeable hybrid aqueous batteries. J. Power Sources 2012, 216, 222-226. [CrossRef]

25. USABC 12V Start-Stop Battery Goals. Available online: http://www.uscar.org/guest/article_view.php? articles_id=85 (accessed on 27 September 2017).

26. Hoang, T.K.A.; Doan, T.N.L.; Cho, J.H.; Ying, J.; Su, J.; Lee, C.; Lu, C.; Chen, P. Sustainable gel electrolyte containing pyrazole as corrosion Inhibitor and dendrite suppressor for aqueous $\mathrm{Zn} / \mathrm{LiMn}_{2} \mathrm{O}_{4}$ battery. ChemSusChem 2017, 10, 2816-2822. [CrossRef] [PubMed]

27. Hoang, T.K.A.; Doan, T.N.L.; Lu, C.; Ghaznavi, M.; Zhao, H.; Chen, P. Performance of thixotropic gel electrolytes in the rechargeable aqueous $\mathrm{Zn} / \mathrm{LiMn}_{2} \mathrm{O}_{4}$ battery. ACS Sustain. Chem. Eng. 2017, 5, 1804-1811. [CrossRef]

28. Sun, K.E.K.; Hoang, T.K.A.; Doan, T.N.L.; Yu, Y.; Zhu, X.; Tian, Y.; Chen, P. Suppression of dendrite formation and corrosion on zinc anode of secondary aqueous batteries. ACS Appl. Mater. Interfaces 2017, 9, 9681-9687. [CrossRef] [PubMed]

29. Hoang, T.K.A.; Doan, T.N.L.; Sun, K.E.K.; Chen, P. Corrosion chemistry and protection of zinc \& zinc alloys by polymer-containing materials for potential use in rechargeable aqueous batteries. RSC Adv. 2015, 5, 41677-41691. [CrossRef]

30. Wang, G.; Qu, Q.; Wang, B.; Shi, Y.; Tian, S.; Wu, Y.; Holze, R. Electrochemical behavior of $\mathrm{LiCoO}_{2}$ in a saturated aqueous $\mathrm{Li}_{2} \mathrm{SO}_{4}$ solution. Electrochim. Acta 2009, 54, 1199-1203. [CrossRef]

31. Wang, G.; Yang, L.; Qu, Q.; Wang, B.; Wu, Y.; Holze, R. An aqueous rechargeable lithium battery based on doping and intercalation mechanisms. J. Solid State Electrochem. 2010, 14, 865-869. [CrossRef]

32. Winter, M.; Besenhard, J.O.; Spahr, M.E.; Novak, P. Insertion electrode materials for rechargeable lithium batteries. Adv. Mater. 1998, 10, 725-763. [CrossRef]

33. Ohzuku, T.; Ueda, A. Solid-state redox reactions of $\mathrm{LiCoO}_{2}(\mathrm{R} \overline{\mathrm{m}})$ for 4 volt secondary lithium cells. J. Electrochem. Soc. 1994, 141, 2972-2977. [CrossRef]

34. Manickam, M.; Singh, P.; Thurgate, S.; Prince, K. Redox behavior and surface characterization of $\mathrm{LiFePO}_{4}$ in lithium hydroxide electrolyte. J. Power Sources 2006, 158, 646-649. [CrossRef]

35. Qu, Q.; Shi, Y.; Tian, S.; Chen, Y.; Wu, Y.; Holze, R. A new cheap asymmetric aqueous supercapacitor: Activated carbon// $\mathrm{NaMnO}_{2}$. J. Power Sources 2009, 194, 1222-1225. [CrossRef]

36. Qu, Q.; Li, L.; Tian, S.; Guo, W.; Wu, Y.; Holze, R. A cheap asymmetric supercapacitor with high energy at high power: Activated carbon/ $/ \mathrm{K}_{0.27} \mathrm{MnO}_{2} \cdot 0.6 \mathrm{H}_{2} \mathrm{O}$. J. Power Sources 2010, 195, 2789-2794. [CrossRef]

37. Qu, Q.; Fu, L.; Zhan, X.; Samuelis, D.; Maier, J.; Li, L.; Tian, S.; Li, Z.; Wu, Y. Porous $\mathrm{LiMn}_{2} \mathrm{O}_{4}$ as cathode material with high power and excellent cycling for aqueous rechargeable lithium batteries. Energy Environ. Sci. 2011, 4, 3985-3990. [CrossRef]

38. Shaju, K.M.; Bruce, P.G. A stoichiometric nano- $\mathrm{LiMn}_{2} \mathrm{O}_{4}$ spinel electrode exhibiting high power and stable cycling. Chem. Mater. 2008, 20, 5557-5562. [CrossRef]

39. Jiao, F.; Bao, J.; Hill, A.H.; Bruce, P.G. Synthesis of ordered mesoporous Li-Mn-O spinel as a positive electrode for rechargeable lithium batteries. Angew. Chem. Int. Ed. 2008, 47, 9711-9716. [CrossRef] [PubMed]

40. Xia, H.; Luo, Z.; Xie, J. Nanostructured $\mathrm{LiMn}_{2} \mathrm{O}_{4}$ and their composites as high-performance cathodes for lithium-ion batteries. Prog. Nat. Sci. 2012, 22, 572-584. [CrossRef]

41. Wang, G.; Qu, Q.; Wang, B.; Shi, Y.; Tian, S.; Wu, Y. An aqueous electrochemical energy storage system based on doping and intercalation: Ppy// $\mathrm{LiMn}_{2} \mathrm{O}_{4}$. ChemPhysChem 2008, 9, 2299-2301. [CrossRef] [PubMed]

42. Lim, S.H.; Cho, J. PVP-assisted $\mathrm{ZrO}_{2}$ coating on $\mathrm{LiMn}_{2} \mathrm{O}_{4}$ spinel cathode nanoparticles prepared by $\mathrm{MnO}_{2}$ nanowire templates. Electrochem. Commun. 2008, 10, 1478-1481. [CrossRef]

43. Wang, X.; Nakamura, H.; Yoshio, M. Capacity fading mechanism for oxygen defect spinel as a $4 \mathrm{~V}$ cathode material in Li-ion batteries. J. Power Sources 2002, 110, 19-26. [CrossRef]

44. Hernán, L.; Morales, J.; Sánchez, L.; Castellón, E.R.; Aranda, M.A.G. Synthesis, characterization and comparative study of the electrochemical properties of doped lithium manganese spinels as cathodes for high voltage lithium batteries. J. Mater. Chem. 2002, 12, 734-741. [CrossRef]

45. Gnanaraj, J.S.; Pol, V.G.; Gedanken, A.; Aurbach, D. Improving the high-temperature performance of $\mathrm{LiMn}_{2} \mathrm{O}_{4}$ spinel electrodes by coating the active mass with $\mathrm{MgO}$ via a sonochemical method. Electrochem. Commun. 2003, 5, 940-945. [CrossRef] 
46. Arumugam, D.; Kalaignan, G.P. Synthesis and electrochemical characterizations of nano-La $\mathrm{O}_{3}-\mathrm{coated}$ nanostructure $\mathrm{LiMn}_{2} \mathrm{O}_{4}$ cathode materials for rechargeable lithium batteries. Mater. Res. Bull. 2010, 45, 1825-1831. [CrossRef]

47. Tarascon, J.M.; Armand, M. Issues and challenges facing rechargeable lithium batteries. Nature 2001, 414, 359-367. [CrossRef] [PubMed]

48. Armand, M.; Tarascon, J.M. Building better batteries. Nature 2008, 451, 652-657. [CrossRef] [PubMed]

49. Kim, T.H.; Park, J.S.; Chang, S.K.; Choi, S.; Ryu, J.H.; Song, H.K. The current move of lithium ion batteries towards the next phase. Adv. Energy Mater. 2012, 2, 860-872. [CrossRef]

50. Iijima, S. Helical microtubules of graphitic carbon. Nature 1991, 354, 56-58. [CrossRef]

51. Jia, X.; Wei, F. Advances in production and applications of carbon nanotubes. Top. Curr. Chem. 2017, $375,18$. [CrossRef] [PubMed]

52. Liu, X.M.; Huang, Z.D.; Oh, S.W.; Zhang, B.; Ma, P.C.; Yuen, M.M.F.; Kima, J.K. Carbon nanotube (CNT)-based composites as electrode material for rechargeable Li-ion batteries: A review. Compos. Sci. Technol. 2012, 72, 121-144. [CrossRef]

53. Journet, C.; Maser, W.K.; Bernier, P.; Loiseau, A.; de la Chapelle, M.L.; Lefrant, S.; Deniard, P.; Lee, R.; Fischer, J.E. Large scale production of single-walled carbon nanotubes by the electric-arc technique. Nature 1997, 388, 756-758. [CrossRef]

54. Rinzler, A.G.; Liu, J.; Dai, H.; Nikolaev, P.; Huffman, C.B.; Rodríguez-Macías, F.J.; Boul, P.J.; Lu, A.H.; Heymann, D.; Colbert, D.T.; et al. Large-scale purification of single-wall carbon nanotubes: Process, product, and characterization. Appl. Phys. A 1998, 67, 29-37. [CrossRef]

55. Pavel, N.; Bronikowski, M.J.; Bradley, R.K.; Rohmund, F.; Colbert, D.T.; Smith, K.A.; Smalley, R.E. Gas-phase catalytic growth of single-walled carbon nanotubes from carbon monoxide. Chem. Phys. Lett. 1999, 313, 91-97. [CrossRef]

56. Ren, Z.F. Synthesis of large arrays of well-aligned carbon nanotubes on glass. Science 1998, 282, 1105-1107. [CrossRef] [PubMed]

57. Zhang, Q.; Huang, J.Q.; Qian, W.Z.; Zhang, Y.Y.; Wei, F. The road for nanomaterials industry: A review of carbon nanotube production, post-treatment, and bulk applications for composites and energy storage. Small 2013, 8, 1237-1265. [CrossRef] [PubMed]

58. Guler, M.O.; Akbulut, A.; Cetinkaya, T.; Akbulut, H. The effect of MWCNT reinforcing on the electrochemical performance of $\mathrm{LiMn}_{2} \mathrm{O}_{4} / \mathrm{MWCNT}$ nanocomposite cathodes. Int. J. Energy Res. 2014, 38, 509-517. [CrossRef]

59. Zhao, X.; Hayner, C.M.; Kung, H.H. Self-assembled lithium manganese oxide nanoparticles on carbon nanotube or graphene as high-performance cathode material for lithium-ion batteries. J. Mater. Chem. 2011, 21, 17297-17303. [CrossRef]

60. Ding, Y.; Li, J.; Zhao, Y.; Guan, L. Direct growth of $\mathrm{LiMn}_{2} \mathrm{O}_{4}$ on carbon nanotubes as cathode materials for lithium ion batteries. Mater. Lett. 2012, 68, 197-200. [CrossRef]

61. Tang, M.; Yuan, A.; Zhao, H.; Xu, J. High-performance $\mathrm{LiMn}_{2} \mathrm{O}_{4}$ with enwrapped segmented carbon nanotubes as cathode material for energy storage. J. Power Sources 2013, 235, 5-13. [CrossRef]

62. Xia, H.; Ragavendran, K.R.; Xie, J.; Lu, L. Ultrafine $\mathrm{LiMn}_{2} \mathrm{O}_{4}$ / carbon nanotube nanocomposite with excellent rate capability and cycling stability for lithium-ion batteries. J. Power Sources 2012, 212, 28-34. [CrossRef]

63. Jia, X.; Yan, C.; Chen, Z.; Wang, R.; Zhang, Q.; Guo, L.; Wei, F.; Lu, Y. Direct growth of flexible $\mathrm{LiMn}_{2} \mathrm{O}_{4} / \mathrm{CNT}$ lithium-ion cathodes. Chem. Commun. 2011, 47, 9669-9671. [CrossRef] [PubMed]

64. Ma, S.B.; Nam, K.W.; Yoon, W.S.; Bak, S.M.; Yang, X.Q.; Cho, B.W.; Kim, K.B. Nano-sized lithium manganese oxide dispersed on carbon nanotubes for energy storage applications. Electrochem. Commun. 2009, 11, 1575-1578. [CrossRef]

65. Hong, H.P.; Kim, M.S.; Lee, Y.H.; Yu, J.S.; Lee, C.J.; Min, N.K. Spray deposition of $\mathrm{LiMn}_{2} \mathrm{O}_{4}$ nanoparticle-decorated multiwalled carbon nanotube films as cathode material for lithium-ion batteries. Thin Sol. Films 2013, 547, 68-71. [CrossRef]

66. Chen, S.; Mi, C.; Su, L.; Gao, B.; Fu, Q.; Zhang, X. Improved performances of mechanical-activated $\mathrm{LiMn}_{2} \mathrm{O}_{4} / \mathrm{MWNT}$ cathode for aqueous rechargeable lithium batteries. J. Appl. Electrochem. 2009, 39, 1943-1948. [CrossRef]

67. Sun, K.; Juarez, D.A.; Huang, H.; Jung, E.; Dillon, S.J. Aqueous lithium ion batteries on paper substrates. J. Power Sources 2014, 248, 582-587. [CrossRef] 
68. Zhu, X.; Doan, T.N.L.; Yu, Y.; Tian, Y.; Sun, K.E.K.; Zhao, H.; Chen, P. Enhancing rate performance of $\mathrm{LiMn}_{2} \mathrm{O}_{4}$ cathode in rechargeable hybrid aqueous battery by hierarchical carbon nanotube/acetylene black conductive pathways. Ionics 2016, 22, 71-76. [CrossRef]

69. Zhu, X.; Wu, X.; Doan, T.N.L.; Tian, Y.; Zhao, H.; Chen, P. Binder-free flexible $\mathrm{LiMn}_{2} \mathrm{O}_{4} /$ carbon nanotube network as high power cathode for rechargeable hybrid aqueous battery. J. Power Sources 2016, 326, 498-504. [CrossRef]

70. Cheng, Q.; Song, Z.; Ma, T.; Smith, B.B.; Tang, R.; Yu, H.; Jiang, H.; Chan, C.K. Folding paper-based lithium-ion batteries for higher areal energy densities. Nano Lett. 2013, 13, 4969-4974. [CrossRef] [PubMed]

71. Kucinskis, G.; Bajars, G.; Kleperis, J. Graphene in lithium ion battery cathode materials: A review. J. Power Sources 2013, 240, 66-79. [CrossRef]

72. Geim, A.K.; Novoselov, K.S. The rise of graphene. Nat. Mater. 2007, 6, 183-191. [CrossRef] [PubMed]

73. Kim, K.J.; Lee, H.; Choi, J.; Lee, H.; Kang, T.; Kim, B.; Kim, S. Temperature dependent structural changes of graphene layers on 6H-SiC (0001) surfaces. Condens. Matter Phys. 2008, 20, 225017. [CrossRef]

74. Balandin, A.A.; Ghosh, S.; Bao, W.; Calizo, I.; Teweldebrhan, D.; Miao, F.; Lau, C.N. Superior thermal conductivity of single-layer graphene. Nano Lett. 2008, 8, 902-907. [CrossRef] [PubMed]

75. Chen, J.H.; Jang, C.; Xiao, S.; Ishigami, M.; Fuhrer, M.S. Intrinsic and extrinsic performance limits of graphene devices on $\mathrm{SiO}_{2}$. Nat. Nanotechnol. 2008, 3, 206-209. [CrossRef] [PubMed]

76. Novoselov, K.S.; Jiang, Z.; Zhang, Y.; Morozov, S.; Stormer, H.; Zeitler, U.; Maan, J.; Boebinger, G.; Kim, P.; Geim, A. Room-temperature quantum Hall effect in graphene. Science 2007, 315, 1379. [CrossRef] [PubMed]

77. Chen, K.S.; Xu, R.; Luu, N.S.; Secor, E.B.; Hamamoto, K.; Li, Q.; Kim, S.; Sangwan, V.K.; Balla, I.; Guiney, L.M.; et al. Comprehensive enhancement of nanostructured lithium-ion battery cathode materials via conformal graphene dispersion. Nano Lett. 2017, 17, 2539-2546. [CrossRef] [PubMed]

78. Jo, G.; Choe, M.; Lee, S.; Park, W.; Kahng, Y.H.; Lee, T. The application of graphene as electrodes in electrical and optical devices. Nanotechnology 2012, 23, 112001. [CrossRef] [PubMed]

79. Novoselov, K.; Jiang, D.; Schedin, F.; Booth, T.; Khotkevich, V.; Morozov, S.; Geim, A. Two-dimensional atomic crystals. Proc. Natl. Acad. Sci. USA 2005, 102, 10451. [CrossRef] [PubMed]

80. Shen, J.; Hu, Y.; Shi, M.; Lu, X.; Qin, C.; Li, C.; Ye, M. Fast and facile preparation of graphene oxide and reduced graphene oxide nanoplatelets. Chem. Mater. 2009, 15, 3514-3520. [CrossRef]

81. Fan, Z.; Yan, J.; Ning, G.; Wei, T.; Zhi, L.; Wei, F. Porous graphene networks as high performance anode materials for lithium ion batteries. Carbon 2013, 60, 558-561. [CrossRef]

82. Ning, G.; Fan, Z.; Wang, G.; Gao, J.; Qian, W.; Wei, F. Gram-scale synthesis of nanomesh graphene with high surface area and its application in supercapacitor electrodes. Chem. Commun. 2011, 47, 5976. [CrossRef] [PubMed]

83. Iezhokin, I.; Offermans, P.; Brongersma, S.; Giesbers, A.; Flipse, C. High sensitive quasi freestanding epitaxial graphene gas sensor on 6H-SiC. Appl. Phys. Lett. 2013, 103, 053514. [CrossRef]

84. Wang, H.; Wang, Y.; Hu, Z.; Wang, X. Cutting and unzipping multiwalled carbon nanotubes into curved graphene nanosheets and their enhanced supercapacitor performance. ACS Appl. Mater. Interfaces 2012, 4, 6827-6834. [CrossRef] [PubMed]

85. Mohammad Choucair, P.T.; John, A. Stride. Gram-scale production of graphene based on solvothermal synthesis and sonication. Nat. Nanotechnol. 2009, 4, 30-33. [CrossRef] [PubMed]

86. Li, D.; Mueller, M.B.; Gilje, S.; Kaner, R.B.; Wallace, G.G. Processable aqueous dispersions of graphene nanosheets. Nat. Nanotechnol. 2008, 3, 101-105. [CrossRef] [PubMed]

87. Mattevi, C.; Kima, H.; Chhowalla, M. A review of chemical vapour deposition of graphene on copper. J. Mater. Chem. 2011, 21, 3324-3334. [CrossRef]

88. Earnshaw, A.; Harrington, T.J. The Chemistry of the Transition Elements; Oxford University Press: Oxford, UK, 1972.

89. McLellan, R.B. The solubility of carbon in solid gold, copper, and silver. Scr. Metal. 1969, 3, 389-391. [CrossRef]

90. López, G.A.; Mittemeijer, E.J. The solubility of C in solid Cu. Scr. Mater. 2004, 51, 1-5. [CrossRef]

91. Oshima, C.; Nagashima, A. Ultra-thin epitaxial films of graphite and hexagonal boron nitride on solid surfaces. J. Phys. Condens. Matter 1997, 9, 1-20. [CrossRef]

92. Baker, H. ASM International Materials, Alloy Phase Diagrams. In ASM Handbook; ASM International Materials: Geauga County, OH, USA, 1992. 
93. Sutter, P.; Hybertsen, M.S.; Sadowski, J.T.; Sutter, E. Electronic structure of rew-layer epitaxial graphene on $\mathrm{Ru}(0001)$. Nano Lett. 2009, 9, 2654. [CrossRef] [PubMed]

94. Sharma, Y.; Sharma, N.; Rao, G.; Chowdari, B. Li-storage and cyclability of urea combustion derived $\mathrm{ZnFe}_{2} \mathrm{O}_{4}$ as anode for Li-ion batteries. Electrochim. Acta 2008, 53, 2380-2385. [CrossRef]

95. Fu, Y.; Wan, Y.; Xia, H.; Wang, X. Nickel ferrite-graphene heteroarchitectures: Toward high-performance anode materials for lithium-ion batteries. J. Power Sources 2012, 213, 338-342. [CrossRef]

96. Wang, Y.; Feng, Z.S.; Chen, J.J.; Zhang, C. Synthesis and electrochemical performance of $\mathrm{LiFePO}_{4} /$ graphene composites by solid-state reaction. Mater. Lett. 2012, 71, 54-56. [CrossRef]

97. Jiang, R.; Cui, C.; Ma, H. Using graphene nanosheets as a conductive additive to enhance the rate performance of spinel $\mathrm{LiMn}_{2} \mathrm{O}_{4}$ cathode material. Phys. Chem. Chem. Phys. 2013, 15, 6406-6415. [CrossRef] [PubMed]

98. Xu, H.; Cheng, B.; Wang, Y.; Zheng, L.; Duan, X.; Wang, L.; Yang, J.; Qian, Y. Improved electrochemical performance of $\mathrm{LiMn}_{2} \mathrm{O}_{4}$ /graphene composite as cathode material for lithium ion battery. Int. J. Electrochem. Sci. 2012, 7, 10627-10632.

99. Jo, K.Y.; Han, S.Y.; Lee, J.M.; Kim, I.Y.; Nahm, S.; Choi, J.W.; Hwang, S.J. Remarkable enhancement of the electrode performance of nanocrystalline $\mathrm{LiMn}_{2} \mathrm{O}_{4}$ via solvothermally-assisted immobilization on reduced graphene oxide nanosheets. Electrochim. Acta 2013, 92, 188-196. [CrossRef]

100. Bak, S.M.; Nam, K.W.; Lee, C.W.; Kim, K.H.; Jung, H.C.; Yang, X.Q.; Kim, K.B. Spinel $\mathrm{LiMn}_{2} \mathrm{O}_{4} /$ reduced graphene oxide hybrid for high rate lithium ion batteries. J. Mater. Chem. 2011, 21, 17309-17315. [CrossRef]

101. Yu, G.; Hu, L.; Vosgueritchian, M.; Wang, H.; Xie, X.; McDonough, J.R.; Cui, X.; Cui, Y.; Bao, Z. Solution-processed graphene $/ \mathrm{MnO}_{2}$ nanostructured textiles for high-performance electrochemical capacitors. Nano Lett. 2011, 11, 2905-2911. [CrossRef] [PubMed]

102. Fan, Z.; Yan, J.; Wei, T.; Zhi, L.; Ning, G.; Li, T.; Wei, F. Asymmetric supercapacitors based on graphene $/ \mathrm{MnO}_{2}$ and activated carbon nanofiber electrodes with high power and energy density. Adv. Funct. Mater. 2011, 21, 2366-2375. [CrossRef]

103. Wu, Z.S.; Ren, W.; Wang, D.W.; Li, F.; Liu, B.; Cheng, H.M. High-energy $\mathrm{MnO}_{2}$ nanowire/graphene and graphene asymmetric electrochemical capacitors. ACS Nano 2010, 4, 5835-5842. [CrossRef] [PubMed]

104. Zhu, X. Nanocarbon-Containing High Power Cathode for Rechargeable Hybrid Aqueous Battery; UWSpace: Waterloo, ON, Canada, 2017. 